\title{
Monitoring the ripening attributes of Turkish white cheese using miniaturized vibrational spectrometers
}

\author{
Hulya Yaman, ${ }^{1,2}$ Didem P. Aykas, ${ }^{1,3}$ Rafael Jiménez-Flores, ${ }^{1}$ and Luis E. Rodriguez-Saona ${ }^{1 *}$ \\ ${ }^{1}$ Department of Food Science and Technology, The Ohio State University, 2015 Fyffe Road, Columbus 43210 \\ ${ }^{2}$ Department of Food Processing, Bolu Abant Izzet Baysal University, Bolu, Turkey 14100 \\ ${ }^{3}$ Department of Food Engineering, Faculty of Engineering, Adnan Menderes University, Aydin, 09100, Turkey
}

\begin{abstract}
Monitoring the ripening process by prevalent analytic methods is laborious, expensive, and time consuming. Our objective was to develop a rapid and simple method based on vibrational spectroscopic techniques to understand the biochemical changes occurring during the ripening process of Turkish white cheese and to generate predictive algorithms for the determination of the content of key cheese quality and ripening indicator compounds. Turkish white cheese samples were produced in a pilot plant scale and ripened for 100 $\mathrm{d}$, and samples were analyzed at $20 \mathrm{~d}$ intervals during storage. The collected spectra (Fourier-transform infrared, Raman, and near-infrared) correlated with major composition characteristics (fat, protein, and moisture) and primary products of the ripening process and analyzed by pattern recognition to generate prediction (partial least squares regression) and classification (soft independent analysis of class analogy) models. The soft independent analysis of class analogy models classified cheese samples based on the unique biochemical changes taking place during the ripening process. partial least squares regression models showed good correlation $\left(\mathrm{R}_{\text {Pre }}=0.87\right.$ to 0.98$)$ between the predicted values by vibrational spectroscopy and the reference values, giving low standard errors of prediction (0.01 to 0.57). Portable and handheld vibrational spectroscopy units can be used as a rapid, simple, and in situ technique for monitoring the quality of cheese during aging and provide real-time tools for addressing deviations in manufacturing.
\end{abstract}

Key words: mid-infrared spectroscopy, near-infrared spectroscopy, Raman spectroscopy, Turkish white cheese, ripening

Received February 16, 2021.

Accepted September 3, 2021.

*Corresponding author: rodriguez-saona.1@osu.edu

\section{INTRODUCTION}

Turkish white cheese, also known as Turkish Beyaz cheese, is produced by following traditional cheese production technology using cow, sheep, or goat milk alone or in mixtures. The fresh cheese is ripened in brine for at least $3 \mathrm{mo}$ or longer (Özer et al., 2011), and during the cheese ripening, complex and dynamic biochemical reactions, including the breakdown of proteins, hydrolysis of fat, and lactose metabolism occur (Fox, 1989; El Soda et al., 1995; McSweeney and Sousa, 2000). The biochemical changes during cheese ripening are essential elements in cheese quality, which could be determined using different analysis techniques such as enzymatic or colorimetric, electrophoresis, and chromatography methods (Martin-del-Campo et al., 2007). Capillary electrophoresis, urea-PAGE, and reverse-phase HPLC have been reported for monitoring organic acids, free AA, peptides, and lactose (Creamer, 1991; Otte et al., 1999; Kilcawley et al., 2001; Izco et al., 2002). Gas chromatography is a common method for determination of free fatty acids, triglycerides, and volatile compounds in cheese (Partidario et al., 1998; Innocente et al., 2000), whereas colorimetric and enzymatic assay are used to measure lactose levels in cheese (Kilcawley et al., 2001). Even though these techniques are accurate and sensitive, they are laborious, expensive, and time consuming, which makes them challenging to use in routine analysis. Furthermore, in each step of cheese processing, it is essential to have in situ and reliable methodologies to control production and standardize the quality of the final product. Thus, there has been a growing interest in implementing nondestructive, rapid, and cost-effective techniques for cheese characterization (Downey et al., 2005).

Vibrational spectroscopy techniques, specifically near-infrared (NIR), Fourier-transform infrared (FTIR), and Raman, are suitable for such applications (LiChan et al., 2006; Boyaci et al., 2015). Near-infrared spectroscopy has shown its potential to quantify the compositional characteristics of various semi-hard 
cheeses in terms of fat, moisture, protein, salt (Karoui et al., 2006a; Madalozzo et al., 2015; Marinoni et al., 2019), volatile compounds (González-Martín et al., 2014), cholesterol, and mineral profile (Manuelian et al., 2017), monitor authentication (Ottavian et al., 2012), and determination of the maturity (Downey et al., 2005). In addition, the unique fingerprinting of FT-IR has been successfully applied for monitoring ripening in Emmental (Karoui et al., 2006b), Cheddar (Fagan et al., 2007; Subramanian et al., 2011), Swiss (RodriguezSaona et al., 2006; Koca et al., 2007), Comté (Boubellouta and Dufour, 2012), and Parmesan (Cevoli et al., 2013) cheeses, and the identification of cheese starter cultures (Prabhakar et al., 2011). Raman spectroscopy has been reported to detect additives in processed cheese (Smith et al., 2017) and monitor for cheese authentication (Sowoidnich and Kronfeldt, 2016). All the research mentioned above was conducted using benchtop units. Recent advancements in optoelectronics have engineered field-deployable and small form-factor units because of miniaturization of the components of spectrometers. Enabling technologies for miniaturization of vibrational spectroscopy units and their applications in the food industry have been covered in review articles by Crocombe (2018) and Rodriguez-Saona et al. (2020).

Our objective was to evaluate handheld and portable vibrational (NIR, FT-IR, and Raman) spectroscopy devices combined with pattern recognition analysis to (1) monitor the biochemical changes occurring during the ripening process of Turkish white cheese and (2) generate predictive algorithms for the rapid and simultaneous determination of cheese quality (fat, protein, and moisture) and ripening indicator compounds (short-chain free fatty acids, total free amino acids, and lactic acid).

\section{MATERIALS AND METHODS}

\section{Cheese Production}

Whole cow milk was obtained from the Ohio State University dairy farm and standardized to 1:1 protein: fat ratios, pasteurized at $65^{\circ} \mathrm{C}$ for $30 \mathrm{~min}$, then cooled to $32^{\circ} \mathrm{C}$ for clotting. The mesophilic culture (Lactococcus lactis ssp. lactis, Lactococcus lactis ssp. cremoris; Choosit MA11, Danisco), recommended for white cheese production was added at $0.002 \%$ level into the milk and left to rest for 15 to 20 min to allow the $\mathrm{pH}$ to reach 6.4. Coagulation was developed in 90 min after adding $0.2 \%$ $\mathrm{CaCl}_{2}$ and a double-strength microbial-derived rennet (Chy-Max, Chr. Hansen). The coagulum was cut into $1-\times 1-\mathrm{cm}$ cubes and allowed to rest for $30 \mathrm{~min}$. The curd was then pressed for $4 \mathrm{~h}$, cut into 7 - $\times 7$-cm cubes, and placed it into a $16 \% \mathrm{NaCl}$ brine solution at $20^{\circ} \mathrm{C}$ for $12 \mathrm{~h}$. Thirty-six white cheese cubes were produced in 2 batches, making 72 cubes for analysis, and each of them weighed approximately $400 \mathrm{~g}$. Cheese blocks were then individually packaged in watertight plastic bags with a $12 \%$ brine solution and placed in a refrigerator $\left(4^{\circ} \mathrm{C}\right)$ until further analysis. The samples were analyzed using spectroscopic techniques and reference methods during the ripening days of $1,20,40,60,80$, and 100 .

\section{Experimental Design}

To show the reproducibility of the study, cheese was produced in 2 different batches, with a total of 36 cheese cubes in each batch; therefore, 72 cheese cubes were produced (36 cubes in each batch $\times 2$ replications). These cheese blocks were divided into 6 groups that were used in each day of analysis $(1,20,40,60,80$, and $100 \mathrm{~d})$, with 12 cheese cubes tested in each testing day.

White cheese has a nonhomogeneous surface and interior cheese structure, and the heterogeneous structure of white cheese has been reported by microscopic evaluation (Boyanova et al., 2012). To limit the compositional variations within cheeses, we collected 4 spectral measurements from different sides (for the FT-IR and Raman instruments) to average these effects. For the FT-IR and Raman spectral measurements, 4 spectra from different sides of each sample were collected for each cube, making $48(12 \times 4)$ spectra collection on each ripening day. To be consistent in the number of collected spectra for all the instruments, 4 spectra from each blended cube were collected for the NIR measurements by scanning different points of the glass petri dish, making 48 spectra collections on each ripening day. Therefore, a total of 288 spectra (48 spectra for each ripening day $\times 6$ ripening days) were collected throughout this study for each spectroscopy unit.

Each reference analysis (total protein, moisture, fat, lactic acid,) was conducted in duplicate from each tested cheese cube, making 24 reference analysis data per ripening day (12 cheese cubes $\times 2$ replications). Before the partial least squares regression (PLSR) analysis, the data set was randomly separated into 2 subgroups as training ( $80 \%$ of the total sample size) and external validation (remaining $20 \%$ ) groups to evaluate the models' robustness. Although we randomly chose samples to generate the calibration and validation sets, we made sure to include samples with all its replications either in the calibration or validation set if the spectra were collected from the NIR instrument. On the contrary, if the spectra were collected from the FTIR and Raman instruments, we made sure to include all spectra from the same cheese cube either in the 
calibration or in the validation set to prevent developing PLSR models prone to overfitting. The models' prediction performance was assessed using the standard error of cross-validation (SECV), coefficient of correlation $(\mathrm{r})$, and outlier diagnostics.

\section{Reference Analysis}

The total protein analysis was performed by the Dumas combustion method (International Organization for Standardization, 2002), and 6.38 was used as a nitrogen-protein conversion factor as suggested in Koletzko and Shamir (2006). The fat content of the samples was determined according to the Gerber method (International Dairy Federation, 2009), and moisture content was determined by the forced draft oven procedure (International Organization for Standardization, 2004).

Lactic acid content of the samples was determined by following Subramanian et al. (2011) and others with slight modifications. A total of $1.5 \mathrm{~g}$ of sample was mixed with chloroform and sonicated (Ultrasonic Dismembrator, Fisher Scientific) for $10 \mathrm{~s}$. Then, $2 \mathrm{~mL}$ of distilled water was added to the mixture and centrifuged (Megafuge 8, Thermo Fisher Scientific) at 3,400 $\times g$ for 5 min at $25^{\circ} \mathrm{C}$. The upper phase first ran through a Sep-Pak C18 Vac solid cartridge (Waters Corp.) then filtered through a $0.2-\mu \mathrm{m}$ nylon filter (Whatman Inc.). The filtrate was eluted using a reverse-phase HPLC (1100, Agilent Technologies) along with a quaternary pump (G1311A), degasser (G1322A), column chamber (G1316A), diode array detector (G1315B), and an ALS autosampler (G1313; all components from Agilent Technologies). The separation of compounds took place in a Prevail organic acid column with dimensions of $150 \times 4.6 \mathrm{~mm} \times 5 \mu \mathrm{m}$ thickness (Hichrom). Phosphate buffer $\left(25 \mathrm{mM} \mathrm{KH_{2 }} \mathrm{PO}_{4}\right)$ at $\mathrm{pH} 2.5$ was used as the mobile phase at the constant flow rate of $1.5 \mathrm{~mL} / \mathrm{min}$. A total of $10 \mu \mathrm{L}$ of the sample was injected through the column, and the chromatograms were automatically integrated for lactic acid at $200 \mathrm{~nm}$. The lactic acid standard curve was developed with the standard concentration range from 22.3 to $222.9 \mu \mathrm{mol} / \mathrm{mL}$.

The free AA profile was determined using an EZ: faast amino acid analysis kit (KG0-7165, Phenomenex Inc.) for GC-MS (7820A, Agilent Technologies). Briefly, the total water-soluble free AA were extracted by ultrasonication of $100 \mathrm{mg}$ of the cheese in $1 \mathrm{~mL}$ of distilled water for $10 \mathrm{~s}$. The mixture was centrifugated at 15,700 $\times g$ for $3 \mathrm{~min}$, and the upper phase was derivatized by using an EZ:faast amino acid analysis kit. The derivatized sample $(1.5 \mu \mathrm{L})$ was injected into a model 7820 GC coupled with a model 5977 mass selective detector
(Agilent Technologies). The amino acid separation was achieved by using a Zebron ZB-AAA column $(10 \mathrm{~m} \times$ $250 \mu \mathrm{m} \times 0.25 \mu \mathrm{m})($ Phenomenex) with a $0.1-\mu \mathrm{m}$ film thickness using helium as the carrier gas. The GC system conditions were 1:15 split injection mode with the injection port set to be $250^{\circ} \mathrm{C}$. The gas flow was set to be constant at $1.1 \mathrm{~mL} / \mathrm{min}$. The oven was programmed to ramp up from $110^{\circ} \mathrm{C}$ to $320^{\circ} \mathrm{C}$ by increasing $30^{\circ} \mathrm{C} /$ min. For the mass spectrometer, the source was set at $240^{\circ} \mathrm{C}$, the quadrupole at $180^{\circ} \mathrm{C}$, the mass transfer line at $310^{\circ} \mathrm{C}$, and the sampling rate at 3.5 scans/sec. Scan mode (with scan range set at $45-450 \mathrm{~m} / \mathrm{z}$ ) was initially used for identification purposes, and selected ion monitoring was later used for quantification. Eighteen AA were quantified, and the most abundant AA were cystine, serine, glutamine, lysine, and asparagine. The major fragment ions $(\mathrm{m} / z)$ that were monitored in the MSD were 44, 60, 84, 30, and 87 for cystine, serine, glutamine, lysine, and asparagine, respectively. The free AA analyses were done in duplicate. The major free AA amount was calculated by summing up the content of cystine, serine, glutamine, lysine, and asparagine.

The fatty acid profile was determined by the esterification of fatty acids to their methyl esters, as reported by Sert et al. (2014) and others with some modifications. The fat of the cheese samples was extracted using a mixture of hexane:methanol $(2: 1 \mathrm{vol} / \mathrm{vol})$ and mixed for 20 min with a rotary shaker (Dynal Biotech, Inc.) at $80 \mathrm{rpm}$. The mixture was centrifuged at low speed (500 $\times g, 5 \mathrm{~min}, 20^{\circ} \mathrm{C}$ ); the upper layer, which consists of the hexane-lipid phase, was transferred to another tube, and the hexane part was evaporated under vacuum. Methyl esters were produced by dissolving $100 \mu \mathrm{L}$ of the oil samples with $10 \mathrm{~mL}$ of hexane and adding 100 $\mu \mathrm{L}$ of $2 N$ potassium hydroxide in methanol solution. The upper layer was transferred into a $2-\mathrm{mL}$ glass GC vial and injected $(1 \mu \mathrm{L})$ with a split ratio of $20: 1$, through a GC (6890N, Agilent Technologies) with a flame ionization detector, an autosampler (HP G1513A; Agilent Technologies), and a tray. The separation of the fatty acids was achieved in an HP-88 capillary column $(100 \mathrm{~m} \times 0.25 \mathrm{~mm} \times 0.2 \mu \mathrm{m}$; Agilent Technologies $)$ using helium as the carrier gas. The inlet temperature and detector were set to $250^{\circ} \mathrm{C}$ and $280^{\circ} \mathrm{C}$, respectively. The oven conditions were kept initially at $60^{\circ} \mathrm{C}$ for 1 min, then increased to $190^{\circ} \mathrm{C}\left(20^{\circ} \mathrm{C} / \mathrm{min}\right)$ and held for $60 \mathrm{~min}$, and finally increased to $220^{\circ} \mathrm{C}\left(1^{\circ} \mathrm{C} / \mathrm{min}\right)$ and held for 10 min. Fatty acid identification was verified by comparing the sample peak retention times and percentage with reference standards (Supelco $37 \mathrm{Com}$ ponent FAME Mix, Sigma-Aldrich). The fatty acids concentrations were determined as percent fatty acid. All the reference analyses were performed in duplicate. 


\section{Vibrational Spectroscopy Analysis}

Near-Infrared Spectrometer Measurements. Cheese samples at different ripening stages were liquid nitrogen powdered by using a stainless steel Waring blender at a pulse setting for 10 s to produce a homogeneous powder. Powdered cheese samples were placed on a $60-\mathrm{mm}$ diameter glass petri dish (Duroplan, DWK Life Sciences), and the content pressed until the sample was compact to avoid air pockets that could cause light scattering. The Fourier transform near infrared spectra were collected using a handheld NIR spectrometer (NeoSpectra-Module, Si-Ware Systems) that uses a single-chip Michelson interferometer with the monolithic opto-electro-mechanical unit and a single uncooled indium-gallium-arsenide photodetector. The glass petri dish was located on a rotating stage that rotates at a constant speed through the NIR spectra collection. The spectra were collected for $20 \mathrm{~s}$, and the collection was completed over the range of 1300 to $2600 \mathrm{~nm}$ in reflectance mode with a resolution of $16 \mathrm{~nm}$.

Mid-Infrared Spectrometer Measurements. Mid-infrared spectra were collected using a portable FT-IR 4500a unit (Agilent Technologies) equipped with a triple-reflection diamond attenuated total reflectance (ATR) accessory. The unit had zinc selenide beam splitter, a low-powered solid-state laser, a wire-wound element infrared source, and a thermoelectrically cooled deuterated triglycine sulfate detector. Cheese samples were placed on the diamond crystal of the unit directly, and the spectra were acquired over the range in 4,000 to $700 \mathrm{~cm}^{-1}$ with a $4 \mathrm{~cm}^{-1}$ resolution and 64 scans coadded to enhance the signal-to-noise ratio.

Raman Spectrometer Measurements. The cheese samples were cut into $2 \times 2 \mathrm{~cm}$ square pieces, and spectral data were directly collected from the cheese. Raman measurements were performed using a Progeny handheld Raman spectrometer (Rigaku Corp.) in the spectral range of 300 to $2,400 \mathrm{~cm}^{-1}$. The Raman unit was equipped with a 1,064nm Nd:YAG laser and thermoelectric-cooled indium-gallium-arsenide array detector. The Raman system was operated with a 490 $\mathrm{mW}$ laser output, and the data were collected at $8 \mathrm{~cm}^{-1}$ resolutions with 30 co-scans for $10 \mathrm{~s}$ integration.

\section{Data Analysis}

The descriptive statistics of reference analysis data were obtained by SPSS software (Version 25, IBM Corp.), and the changes during the ripening period were examined by general linear model repeated measures analysis.
The data obtained from the vibrational spectroscopy equipment were analyzed using Pirouette software (Version 4.5, Infometrix Inc.). All data were mean-centered and transformed using the normalization and SavitzkyGolay second derivative (35-point window gap) functions. Classification of the white cheese samples at the different ripening stages (d $1,20,40,60,80,100)$ was evaluated using soft independent modeling of class analogy (SIMCA). The biochemical changes in the major compounds in the white cheese were quantified using PLSR.

The supervised pattern recognition classification technique SIMCA employs information on class membership of samples (d 1: class 1, d 20: class 2, d 40: class 3, d 60: class 4, d 80: class 5, and d 100: class 6) (Berrueta et al., 2007). New samples (unknowns) are assigned to classes by comparing the residual variance of the new sample to the average residual variance of the classes in the model through an F-test (Checa-Moreno et al., 2014). The SIMCA model performance for each vibrational spectroscopic equipment was evaluated by assessing the class projections, misclassified samples, and interclass distances (ICD). The ICD is a unitless measure to describe the similarity or dissimilarity of the classes, and an ICD over 3.0 indicates classes are significantly distinct from each other (Vogt and Knutsen, 1985). Moreover, the classification models' performances were also evaluated by determining the accuracy, sensitivity, and specificity based on true positive (TP; predicted class and actual class are both positive), false positive (FP; predicted class is positive whereas the actual class is negative), true negative (TN; predicted class and the actual class are both negative) and false negative (FN; predicted result is negative whereas the actual label is positive) classifiers (Linden, 2006). Accuracy can be calculated from $[(\mathrm{TP}+\mathrm{TN}) /(\mathrm{TP}+\mathrm{TN}+$ $\mathrm{FP}+\mathrm{FN})] \times 100$, whereas sensitivity can be calculated from $[(\mathrm{TP}) /(\mathrm{TP}+\mathrm{FN})] \times 100$, and specificity can be calculated from $[(\mathrm{TN}) /(\mathrm{TN}+\mathrm{FP})] \times 100$ (Šimundić, 2009).

Measured reference values, including fat, protein, moisture, lactic acid, short-chain fatty acids, and major free AA content were correlated with the collected spectral data using PLSR modeling. Before the PLSR analysis, the data set was randomly separated into 2 subgroups as training ( $80 \%$ of the total sample size) and external validation (remaining 20\%) groups to evaluate the models' robustness. The models' prediction performance was assessed using the SECV, coefficient of correlation (r), and outlier diagnostics. During the PLSR modeling calibration and validation steps, samples with large studentized residual $(>3)$ or 
Table 1. Changes (mean $\pm \mathrm{SD}$ ) in protein, fat, moisture, lactic acid, total free AA (TFAA), and short-chain fatty acids (SCFA) in white cheese during the ripening period

\begin{tabular}{|c|c|c|c|c|c|c|}
\hline \multirow[b]{2}{*}{ Item } & \multicolumn{6}{|c|}{ Ripening day } \\
\hline & 1 & 20 & 40 & 60 & 80 & 100 \\
\hline Fat in DM $(\%)$ & $48.5 \pm 0.3^{\mathrm{a}}$ & $48.7 \pm 0.2^{\mathrm{ab}}$ & $49.0 \pm 0.2^{\mathrm{b}}$ & $49.9 \pm 0.2^{\mathrm{c}}$ & $50.3 \pm 0.2^{\mathrm{d}}$ & $50.7 \pm 0.2^{\mathrm{e}}$ \\
\hline Moisture (\%) & $57.2 \pm 0.2^{\mathrm{a}}$ & $57.9 \pm 0.2^{\mathrm{b}}$ & $58.2 \pm 0.2^{\mathrm{bc}}$ & $58.8 \pm 0.2^{\mathrm{c}}$ & $59.2 \pm 0.2^{\mathrm{cd}}$ & $60.0 \pm 0.3^{\mathrm{d}}$ \\
\hline Lactic acid (\%) & $1.5 \pm 0.1^{\mathrm{a}}$ & $1.6 \pm 0.1^{\mathrm{b}}$ & $1.8 \pm 0.1^{\mathrm{b}}$ & $1.9 \pm 0.1^{\mathrm{c}}$ & $2.2 \pm 0.1^{\mathrm{d}}$ & $2.7 \pm 0.1^{\mathrm{e}}$ \\
\hline TFAA $(\mu \mathrm{mol} / \mathrm{g})$ & $0.45 \pm 0.01^{\mathrm{a}}$ & $0.46 \pm 0.01^{\mathrm{b}}$ & $0.47 \pm 0.01^{\mathrm{c}}$ & $0.48 \pm 0.01^{\mathrm{d}}$ & $0.49 \pm 0.01^{\mathrm{e}}$ & $0.50 \pm 0.01^{\mathrm{f}}$ \\
\hline
\end{tabular}

${ }^{\mathrm{a}-\mathrm{f}}$ Means with different superscript letters in the same row indicates significant differences $(P<0.05)$.

high leverage were re-evaluated and excluded from the models if needed.

\section{RESULTS AND DISCUSSION}

\section{Compositional Changes During the Ripening Period}

The changes in the chemical composition of Turkish white cheese during the ripening period $(\mathrm{d} 1,20,40$, 60,80 , and 100) are presented in Table 1 . The ripening process showed significant changes in the chemical composition of cheese samples $(P<0.05)$. Although protein content decreased, moisture, fat in DM, lactic acid, total free AA, and short-chain fatty acid contents increased during the ripening (Table 1). Changes in protein and moisture content in the ripening cheese may result from breaking peptide bonds, increasing water-binding capacities of peptides, or the diffusion of soluble nitrogen to brine by proteolysis, and increase in the moisture content by the diffusion of the brine into the cheese (Hayaloglu et al., 2002; Atasoy and Türkoğlu, 2008).

The breakdown of proteins into peptides and AA with the contribution of proteolysis during the ripening period resulted in a significant increase in the free amino acid concentration (Table 1). In addition to proteolysis, the formation of short-chain fatty acids increased significantly from d 1 to d 100, which was consistent with the literature reported in Turkish white cheese by other researchers (Özer et al., 2011). Although the fat content was anticipated to decrease because of the lipolysis, our results showed an increase in the fat in DM content through the ripening period (Table 1). This could be related to the diffusion of moisture into the cheese or leaching out of the salts, particularly calcium phosphate due to the acidity and then lower the TS content (Walstra et al., 2006).

Lactic acid formation through the white cheese ripening (d 1 to 100) increased significantly (Table 1).
Addition of the starter culture in cheese production promotes lactic acid formation through the conversion of lactose to lactic acid to inhibit the growth of the undesirable microorganisms, providing flavor development and ultimately obtaining a high-quality cheese (Walstra et al., 2006).

\section{Spectral Characterization of White Cheese Samples}

The Raman and infrared spectral bands were assigned by comparing our recorded wave numbers and wavelengths with the reported regions by other researchers. Example of an FT-IR, NIR, and Raman spectra collected over storage are given in Figure 1. Figure 1a shows the overlaid FT-IR spectra $\left(4,000-700 \mathrm{~cm}^{-1}\right)$ of white cheese samples on $\mathrm{d} 1$ and 100, exhibiting noticeable changes during the ripening process. First, samples showed differences in the spectral range between 3,700 and $3,000 \mathrm{~cm}^{-1}$ from the increased moisture content through the ripening period. The absorbance bands at approximately $2,955,2,920$, and $2,850 \mathrm{~cm}^{-1}$ showed $-\mathrm{C}-\mathrm{H}$ symmetric and asymmetric stretching related to fatty acids. The region in 1,750 to $1,700 \mathrm{~cm}^{-1}$ related to the $\mathrm{C}=\mathrm{O}$ stretching of acids and esters. The absorbance band at $1,742 \mathrm{~cm}^{-1}$ associated with the acid end groups of fatty acids, AA, and organic acids present in the cheese samples. The spectral range in 1,680 to 1,239 $\mathrm{cm}^{-1}$ related to the proteins; particularly the ranges 1,680 to $1,631 \mathrm{~cm}^{-1}, 1,560$ to $1,533 \mathrm{~cm}^{-1}$, and 1,472 to $1,239 \mathrm{~cm}^{-1}$ are associated with amide I, amide II, and amide III, respectively. Amide I vibration principally results from the $\mathrm{C}-\mathrm{O}$ stretching of proteins with $\mathrm{CN}$, $\mathrm{CNN}$, and $\mathrm{NH}$ stretching. The out of phase combination of $\mathrm{NH}$ and $\mathrm{CN}$ stretching, with $\mathrm{CO}, \mathrm{CC}, \mathrm{NC}$ stretching, forms the amide II vibrations. Finally, amide III, the $\mathrm{N}$-methyl acetamide mode, is the combination of $\mathrm{NH}$ bending and CN stretching (Barth, 2007). Differences in this spectral range resulted from the development of the proteolysis, lipolysis, and lactose metabolism dur- 


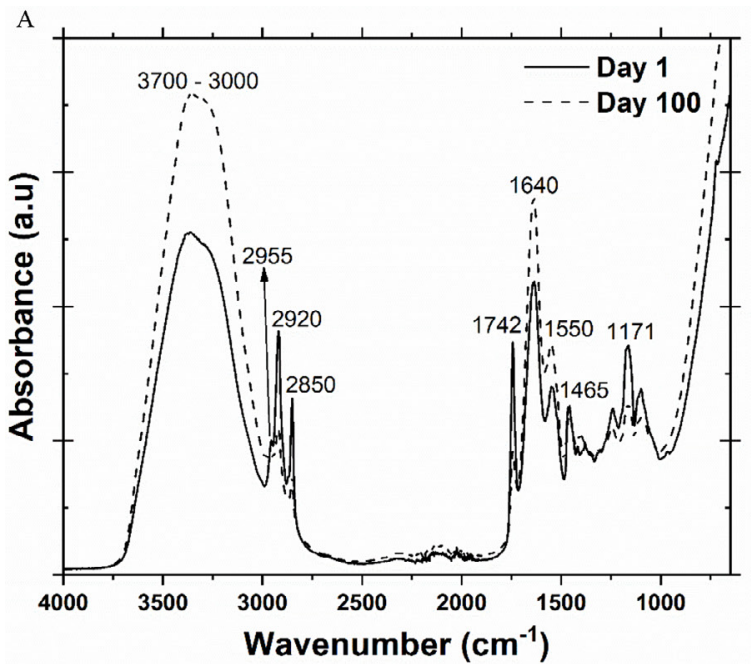

B

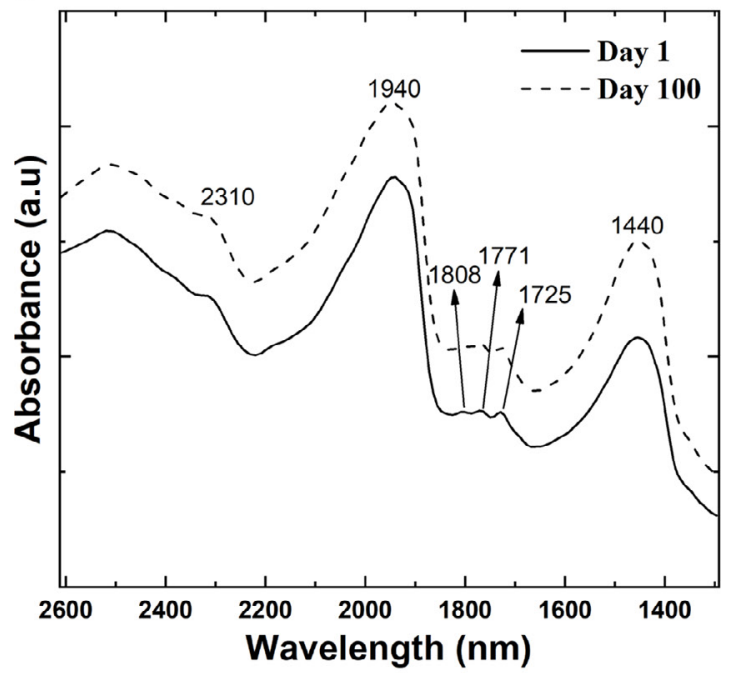

$\mathrm{C}$

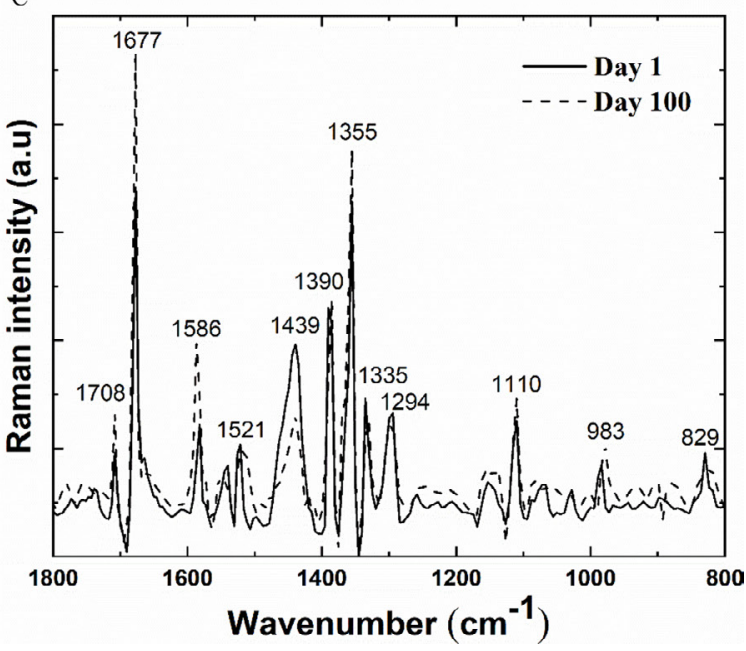

Figure 1. Characteristic raw spectra of Turkish white cheese samples on d 1 and 100, were collected using portable (A) Fouriertransform infrared $\left(650-4,000 \mathrm{~cm}^{-1}\right)$, (B) Fourier-transform near infrared (FT-NIR) $(1,300-2,600 \mathrm{~nm})$, and (C) Raman $\left(800-1,800 \mathrm{~cm}^{-1}\right)$ spectroscopic equipment. ing the ripening period (Subramanian et al., 2011). The absorbance bands in the 1,000 to $1,200 \mathrm{~cm}^{-1}$ region are related to $\mathrm{C}-\mathrm{C}, \mathrm{C}-\mathrm{O}$ stretching of carbohydrates, and fatty acid groups (Grube et al., 2002; Rodriguez-Saona et al., 2006; Nicolaou et al., 2010).

The typical NIR spectra (d 1 and 100) collected in the 2,600 to $1,300 \mathrm{~nm}$ region are given in Figure $1 \mathrm{~b}$. The 2 broad and dominant bands at around 1,440 and $1,940 \mathrm{~nm}$ are attributed to water (Buning-Pfaue, 2003). The absorption bands centered in 1,725, 1,771, 1,808, and $2,310 \mathrm{~nm}$ were observed as the contribution of lipids (Downey et al., 2005). The region between 1,725 and $1,808 \mathrm{~nm}$ is the first overtone of $\mathrm{C}-\mathrm{H}$ stretches, and $2,310 \mathrm{~nm}$ is the combination bands from $\mathrm{C}-\mathrm{H}$ stretch and deformation of $\mathrm{CH}_{2}$ groups. The bands at around 2,148 and 2,200 $\mathrm{nm}$ are assigned to the combinations of $\mathrm{N}-\mathrm{H}$ and $\mathrm{O}-\mathrm{H}$ bonds, respectively (Karoui et al., 2006a).

A typical Raman spectrum of white cheese samples for the ripening periods of 1 and 100 is presented in Figure 1c. The characteristic Raman spectra of white cheese were mainly associated with proteins, AA, lipids, and carbohydrates based on the previous assignments in the literature (Furukawa et al., 1993; Ngarize et al., 2004; Podstawka et al., 2007; Alajtal et al., 2010; Trebolazabala et al., 2013; Rygula et al., 2013; Zając et al., 2014; Boyaci et al., 2015; Corvucci et al., 2015; Czamara et al., 2015; Smith et al., 2017; Lambert et al., 2018). The prominent bands in the Raman spectra were centered at $829 \mathrm{~cm}^{-1}$ associated with the out of plane $\mathrm{COO}$ bending modes of lactic acid, phenylalanine, leucine, and valine, the band at $986 \mathrm{~cm}^{-1}$ was associated with amide III antiparallel $\beta$-sheet structure. The bands between 1,070 and $1,077 \mathrm{~cm}^{-1}$ were related to the bending vibrations of $\mathrm{CH}, \mathrm{COH}, \mathrm{CN}$ functional groups of proteins, the region between 1,110 and $1,180 \mathrm{~cm}^{-1}$ was associated with $\delta\left(\mathrm{CH}_{2}\right)$ twisting vibrations of SFA. The band at $1,294 \mathrm{~cm}^{-1}$ related to $\mathrm{CH}_{2}$ twisting and $=\mathrm{C}-\mathrm{H}$ bending $($ cis $)$ of fats, especially myristic acid. Furthermore, the band at $1,335 \mathrm{~cm}^{-1}$ was associated with the proteins (amide III $\alpha$-helix structure), and the band at $1,355 \mathrm{~cm}^{-1}$ related to tryptophan (Pézolet et al., 1980; Schweitzer-Stenner et al., 2002; Ren et al., 2013). The bands at 1,390 and 1,447 were associated with $\mathrm{CH}_{2}$ scissoring and $\mathrm{CH}_{2}$ bending with the contribution of $-\mathrm{CH}_{2}$ deformation of fats and carbohydrates. The bands at 1,521 and $1,585 \mathrm{~cm}^{-1}$ were associated with $\mathrm{C}=\mathrm{C}$ vibration of tyrosine and $-\mathrm{COOH}$ asymmetric stretching vibration of acids, respectively. Last, the regions between 1,665 and $1,650 \mathrm{~cm}^{-1}$ and 1,680 to $1,670 \mathrm{~cm}^{-1}$ were related to $\mathrm{C}=\mathrm{C}$ stretching of the cis and trans configurations within UFA, and the region at 1,800 to $1,700 \mathrm{~cm}^{-1}$ was related to the $\nu(\mathrm{C}=\mathrm{O})$ ester carbonyl stretching. 

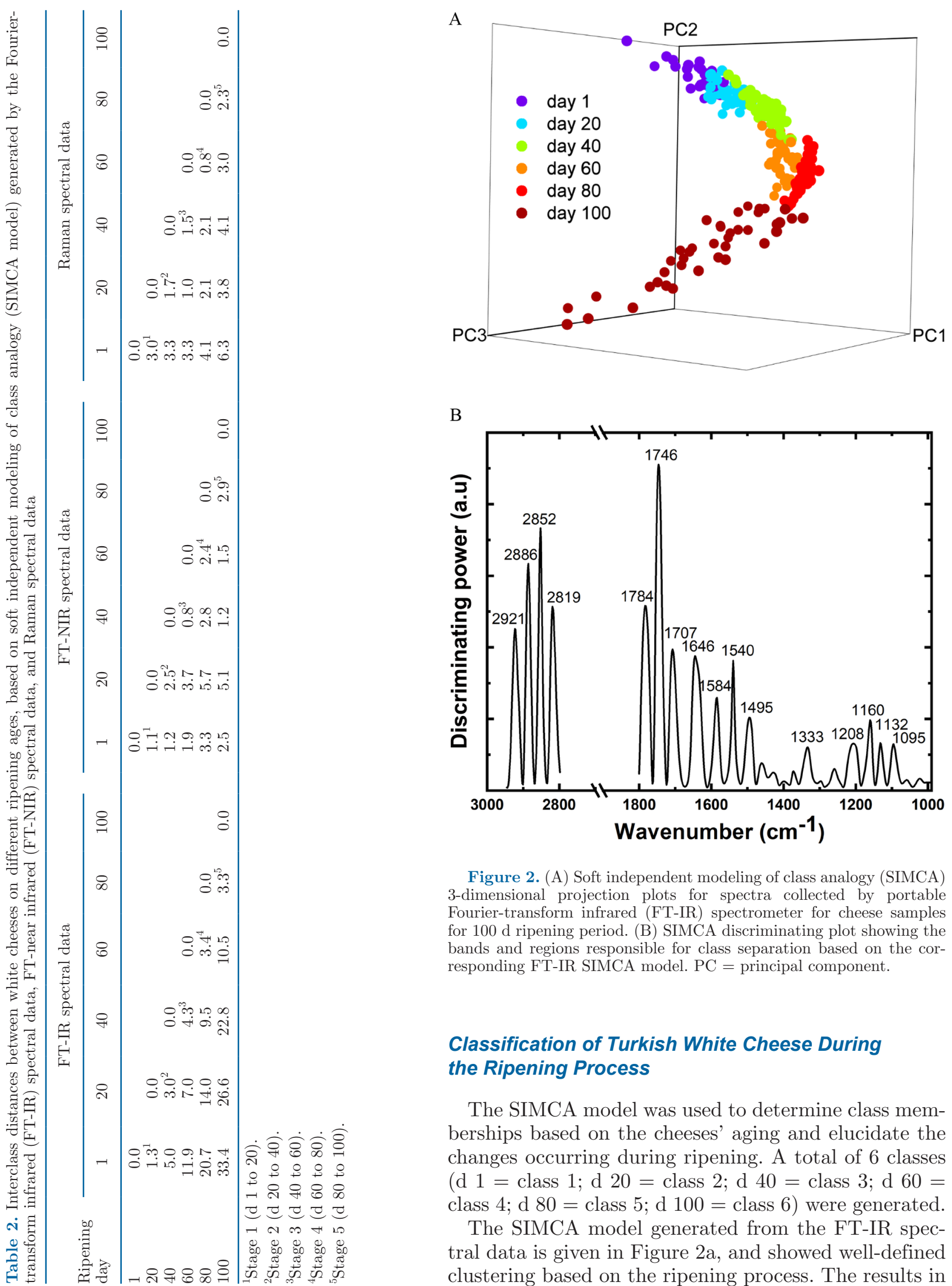

Figure 2. (A) Soft independent modeling of class analogy (SIMCA) 3-dimensional projection plots for spectra collected by portable Fourier-transform infrared (FT-IR) spectrometer for cheese samples for $100 \mathrm{~d}$ ripening period. (B) SIMCA discriminating plot showing the bands and regions responsible for class separation based on the corresponding FT-IR SIMCA model. PC = principal component.

\section{Classification of Turkish White Cheese During the Ripening Process}

The SIMCA model was used to determine class memberships based on the cheeses' aging and elucidate the changes occurring during ripening. A total of 6 classes (d $1=$ class 1 ; d $20=$ class 2 ; d $40=$ class 3 ; d $60=$ class $4 ; \mathrm{d} 80=$ class $5 ; \mathrm{d} 100=$ class 6 ) were generated.

The SIMCA model generated from the FT-IR spectral data is given in Figure 2a, and showed well-defined clustering based on the ripening process. The results in 
Table 2a show the separation of classes according to the interclass distance (Mahalanobis distance) that illustrates good separation of classes. The ICD ranged from 1.3 to 33.4 (Table 2a) with values larger than 3 indicating that models are independent of one another. The lowest ICD was observed for classes between $\mathrm{d} 1$ and d $20(\mathrm{ICD}=1.3)$, which suggests those 2 stages share the highest similarities, and the biochemical changes in the cheese were not marked enough to discriminate the classes yet. After d 20, the changes that occurred during cheese ripening were enough to significantly discriminate them, with the highest ICD reported for classes on $\mathrm{d} 1$ and $\mathrm{d} 100(\mathrm{ICD}=33.4)$. In addition, ICD showed noteworthy differences taking place between 40 and $60 \mathrm{~d}(\mathrm{ICD}=4.3)$ and 60 and $80 \mathrm{~d}(\mathrm{ICD}=3.4)$.

The discriminating power plot is a diagnostic feature of SIMCA that gives information of which functional groups or variables (wave numbers) are responsible for the separation of the classes. The discriminating power plot for the FT-IR model (Figure 2b) showed that most of the model variance was explained by bands centered at 1,095 to $1,208 \mathrm{~cm}^{-1}$ that corresponds to changes in lactic acid content during ripening (Martin-del-Campo et al., 2007). The bands between 1,495 to $1,700 \mathrm{~cm}^{-1}$ were associated with proteins and AA, particularly the bands at around $1,646 \mathrm{~cm}^{-1}$ and $1,540 \mathrm{~cm}^{-1}$ were related to amide I and II, respectively (Martin-delCampo et al., 2007) and the range between 1,705 and $1,785 \mathrm{~cm}^{-1}$ related to the $\mathrm{C}=\mathrm{O}$ groups of fatty acid esters (Rodriguez-Saona et al., 2006; Subramanian et al., 2011). Last, the bands between 2,800 and 3,000 $\mathrm{cm}^{-1}$ associated with the asymmetric and symmetric stretching vibrations of $\mathrm{CH}_{2}$ of long-chain fatty acids (Posati and Orr, 1976).

The SIMCA 3-D projection plot for NIR spectra of white cheeses at different ripening stages is shown in Figure 3a. The ICD for the ripening stages ranged from 0.8 to 5.7 (Table $2 \mathrm{~b}$ ) and showed that most of the models were not independent of each other $(\mathrm{ICD}<3)$, revealing that NIR showed limited resolution of classes at different stages of cheese ripening, both visually in the class projections and quantitatively from the ICD metric. The evaluation of the discriminating power plot corresponding to the NIR SIMCA model showed that the separation of different ripening age of cheese was explained by the NIR spectral regions between 1,600 and 2,450 nm (Figure 3b). The important bands were attributed to $\mathrm{C}-\mathrm{H}$ stretching of the first overtone of $\mathrm{CH}_{2}$ and $\mathrm{CH}_{3}$ that is associated with lipids (1,600 to 1,780 nm) (Downey et al., 2005; Shenk et al., 2008), and $\mathrm{N}-\mathrm{H}$ bending of protein and amide II and II $(2,040$ to $2,190 \mathrm{~nm}$; Shenk et al., 2008).

The SIMCA analysis of the Raman spectra showed good discrimination between classes (Figure 4a); the
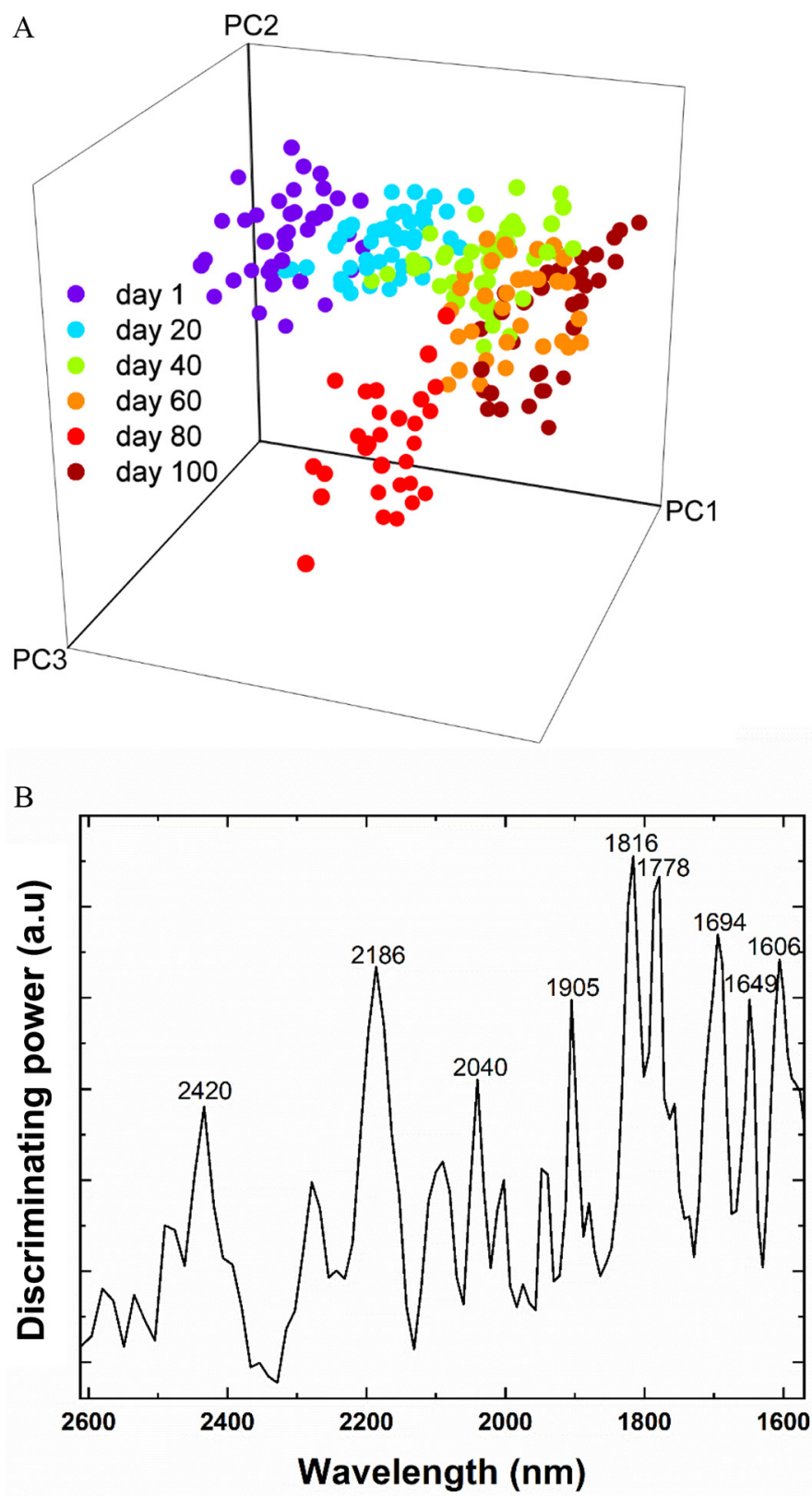

Figure 3. (A) Soft independent modeling of class analogy (SIMCA) 3-dimensional projection plots for spectra collected by portable Fourier-transform near infrared (FT-NIR) spectrometer for cheese samples for 100-d ripening period. (B) SIMCA discriminating plot showing the bands and regions responsible for class separation based on the corresponding FT-NIR SIMCA model. PC = principal component.

ICD for the classes ranged from 0.8 to 6.3 , with the highest ICD observed in the classes between $\mathrm{d} 1$ and $\mathrm{d}$ $100(\mathrm{ICD}=6.3$; Table $2 \mathrm{c}$ ). The discriminating power plot corresponding to the SIMCA model obtained with the Raman data is given in Figure 4b. According to the discriminating power plot, the discrimination of different ripening stages was explained by the following 
predominant bands: $977 \mathrm{~cm}^{-1}$ related to $\delta(=\mathrm{C}-\mathrm{H})(\mathrm{Ar}-$ gov et al., 2008), 1,115 $\mathrm{cm}^{-1}$ associated with aliphatic $\mathrm{C}-\mathrm{C}$ stretch all-trans, $(=\mathrm{CH})$ olefinic hydrogen bending, and $\left(\mathrm{CH}_{2}\right)$ methylene scissor deformations (Genis et al., 2021). The bands at 1,335 and $1,390 \mathrm{~cm}^{-1}$ are associated with the amide III and $\mathrm{CH}_{2}$ scissoring and bending by the contribution of $\mathrm{CH}_{2}$ deformation of fats, respectively (Schweitzer-Stenner et al., 2002). The band at $1,516 \mathrm{~cm}^{-1}$ is an indication of changes in aroma profile with $\mathrm{C}=\mathrm{C}$ vibration of tyrosine and aromatic compounds (Furukawa et al., 1993). The band at 1,591 $\mathrm{cm}^{-1}$ indicates the changes in organic acid content with $\mathrm{COOH}$ stretching (Podstawka et al., 2007). The SIMCA results obtained from the spectral evaluation provided a compatible outcome with the reference data generated by classical analytical techniques (Table 1).

In addition to the ICD, models were also evaluated by the misclassification algorithm that showed that all samples were correctly assigned to their corresponding classes. Furthermore, model prediction diagnostics, including accuracy, sensitivity, and specificity, were calculated for the SIMCA models generated with all 3 instruments (FT-IR, NIR, and Raman) and all models provided $100 \%$ accuracy, sensitivity, and specificity, which means the generated models could effectively determine all the cheese samples in their correct groups.

To observe the biochemical changes at individual ripening stages, separate SIMCA models were developed evaluating fresh cheese $(\mathrm{d} 1)$ and each cheese at a different ripening stage (d 20,40,60, 80, and 100). The changes in each stage in the FT-IR and Raman spectra were monitored through the discriminating power plot (Figure 5). Typically, the Raman active molecules are not IR active and vice versa; therefore, techniques are considered to complement each other (Hashimoto et al., 2019). Thus, the band changes during ripening by those 2 techniques (FT-IR and Raman) are shown by overlapping their signal in the same figure (Figure 5). Briefly, on d 1 to 20 (Figure 5a), the FT-IR spectra revealed the main changes occurred at the organic acids $\left(1,220-1,100 \mathrm{~cm}^{-1}\right)$, amino acids $\left(1,430-1,300 \mathrm{~cm}^{-1}\right)$, and fatty acids $(2,900-2,800,1,750-1,700,1,460-1,350$ $\mathrm{cm}^{-1}$ ) regions (Barth, 2007; Oleszko et al., 2015) and the Raman spectra exhibited changes associated mainly with the protein $\left(1,216 \mathrm{~cm}^{-1} ; 1,132 \mathrm{~cm}^{-1}\right)$ and fat $\left(1,641 \mathrm{~cm}^{-1} ; 1,454 \mathrm{~cm}^{-1}\right)$ metabolism (De Gelder et al., 2007; Smith et al., 2017).

On d 40 (Figure 5b), the main differences revealed by FT-IR were related to organic acids $\left(1,150-900 \mathrm{~cm}^{-1}\right)$, fat $\left(2,900-2,800,1,750-1,700,1,460-1,350 \mathrm{~cm}^{-1}\right)$ and protein $\left(1,430-1,300 \mathrm{~cm}^{-1}\right)$ metabolism. For the same timeframe, the Raman unit revealed that lipids $(1,641$, 1,454 , and $\left.1,097 \mathrm{~cm}^{-1}\right)$ and protein $(1,200$ and 1,132 $\mathrm{cm}^{-1}$ ) were important in the initial stages of ripening (Barth, 2007; De Gelder et al., 2007; Subramanian et al., 2011; Oleszko et al., 2015; Smith et al., 2017). On d 60 , the FT-IR model shows the prevalence of lipolysis $\left(2,900-2,800 \mathrm{~cm}^{-1}, 1,790-1,700 \mathrm{~cm}^{-1}, 1,450-1,400 \mathrm{~cm}^{-1}\right)$ followed by proteolysis $\left(1,790-1,650 \mathrm{~cm}^{-1}, 1,550-1,470\right.$ $\mathrm{cm}^{-1}$; Figure 5c), even though the changes in organic acids were still observed $\left(1,150-900 \mathrm{~cm}^{-1}\right)$. According to the Raman spectra, protein and amino acid metabolisms $\left(1,595 \mathrm{~cm}^{-1}, 1,132 \mathrm{~cm}^{-1}\right)$ in white cheese resulted

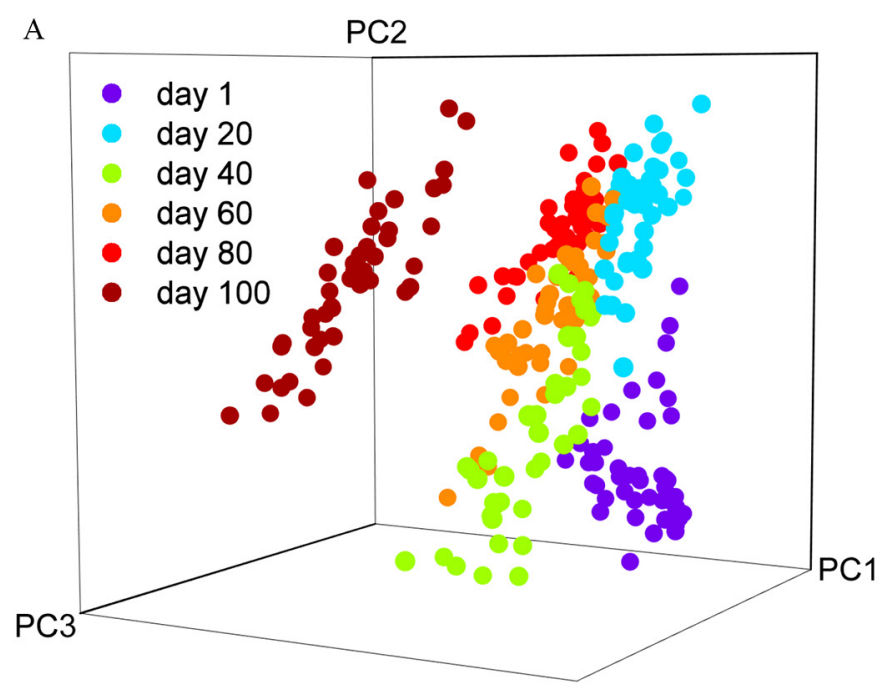

B

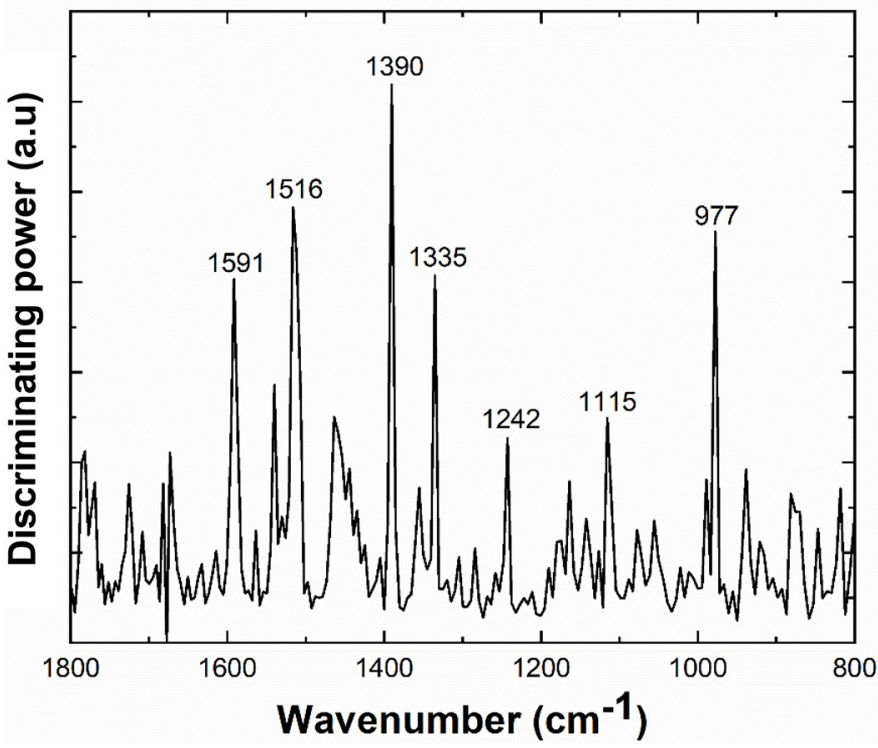

Figure 4. (A) Soft independent modeling of class analogy (SIMCA) 3-dimensional projection plots for spectra collected by portable Raman spectrometer for cheese samples for 100-d ripening period. (B) SIMCA discriminating plot showing the bands and regions responsible for class separation based on the corresponding Raman SIMCA model. PC = principal component. 


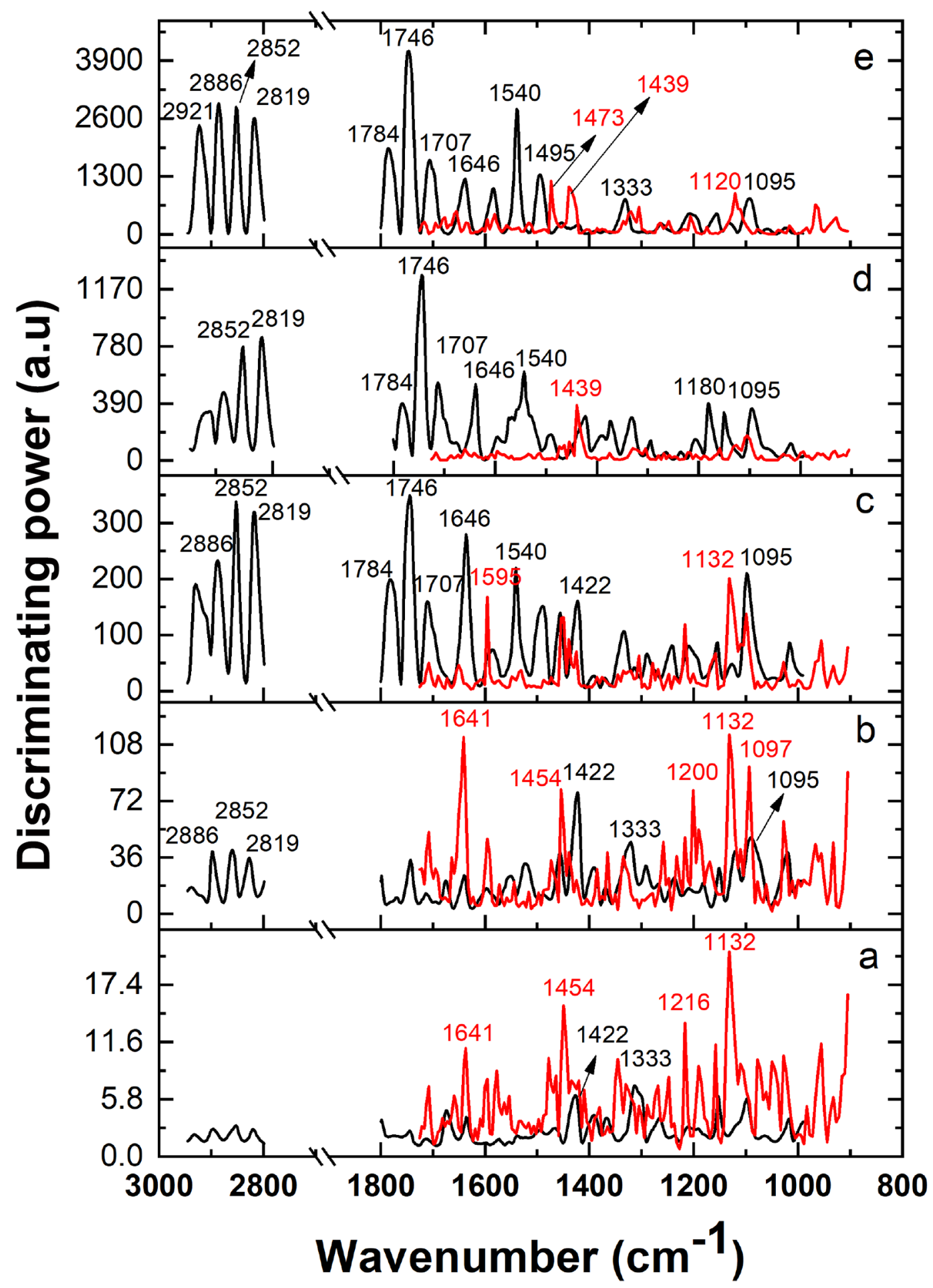

Figure 5. Soft independent modeling of class analogy (SIMCA) discriminating plots for the Fourier-transform infrared (FT-IR) and Raman data showing the spectral changes during the ripening of white cheese from (a) d 0 to 20, (b) d 0 to 40, (c) d 0 to 60, (d) d 0 to 80, and (e) d 0 to 100 .

in significant spectral changes and class separation. Based on the FT-IR spectra, on d 80 and 100 (Figure $5 \mathrm{~d}$ and e), lipolysis was the major biochemical change in ripened white cheese, but some protein and organic acid metabolism were still observed. The Raman spectra highlight the compositional changes related to 
Table 3. Performance statistics of the calibration and the validation models developed using near infrared (NIR), Fourier-transform infrared (FT-IR), and Raman spectroscopy for the prediction of fat, protein, moisture, lactic acid, total free AA (TFAA), and short-chain fatty acids (SCFA) in cheese samples during the ripening period ${ }^{1}$

\begin{tabular}{|c|c|c|c|c|c|c|c|c|c|c|}
\hline Method & Item & \multicolumn{5}{|c|}{ Calibration model } & \multicolumn{4}{|c|}{ Validation model } \\
\hline \multirow[t]{4}{*}{ NIR } & Fat & $19.2-21.9$ & 187 & 4 & 0.32 & 0.90 & $19.4-21.8$ & 44 & 0.34 & 0.90 \\
\hline & Moisture & $57.1-60.3$ & 200 & 4 & 0.32 & 0.94 & $57.8-60.2$ & 48 & 0.38 & 0.91 \\
\hline & Lactic acid & $1.4-2.8$ & 192 & 5 & 0.18 & 0.89 & $1.5-2.7$ & 48 & 0.19 & 0.89 \\
\hline & TFAA & $0.4-0.5$ & 194 & 4 & 0.01 & 0.91 & $0.4-0.5$ & 46 & 0.01 & 0.91 \\
\hline \multirow{4}{*}{ FT-IR } & Moisture & $57.0-60.3$ & 206 & 4 & 0.26 & 0.95 & $57.1-60.1$ & 49 & 0.25 & 0.96 \\
\hline & Lactic acid & $1.4-2.8$ & 205 & 5 & 0.09 & 0.97 & $1.4-2.8$ & 51 & 0.08 & 0.97 \\
\hline & TFAA & $0.4-0.5$ & 207 & 5 & 0.01 & 0.97 & $0.4-0.5$ & 50 & 0.01 & 0.97 \\
\hline & SCFA & $2.2-6.9$ & 223 & 4 & 0.48 & 0.93 & $2.2-6.9$ & 50 & 0.40 & 0.96 \\
\hline \multirow[t]{2}{*}{ Raman } & Fat & $19.0-21.8$ & 212 & 5 & 0.26 & 0.95 & $18.9-21.8$ & 53 & 0.27 & 0.94 \\
\hline & Protein & $13.5-16.7$ & 216 & 5 & 0.24 & 0.95 & $13.8-16.4$ & 53 & 0.23 & 0.95 \\
\hline
\end{tabular}

${ }^{1} \mathrm{SECV}=$ standard error of cross-validation; $\mathrm{R}_{\mathrm{CV}}=$ correlation coefficient of cross-validation; $\mathrm{SEP}=$ standard error of prediction; $\mathrm{R}_{\mathrm{Pre}}=$ correlation coefficient of prediction.

lipolysis $\left(1,439 \mathrm{~cm}^{-1}\right.$ and $\left.1,473 \mathrm{~cm}^{-1}\right)$ and to a lesser extent proteolysis $\left(1,120 \mathrm{~cm}^{-1}\right.$; De Gelder et al., 2007).

\section{Developing the PLSR Models}

The spectral data collected using portable vibrational spectroscopy equipment were used to develop quantitative PLSR models based on the reference values for fat, protein, moisture, lactic acid, short-chain fatty acid, and major free AA content. The cheese sample spectra were randomly divided into 2 subgroups, as training or calibration ( $80 \%$ of the total data) and external validation sets (the remaining 20\%). The results of the PLSR models for the calibration and validation sets are given in Table 3. The few outliers or the samples with high leverages were taken out of the models; therefore, the sample size is not the same for all the models. The calibration models were generated using full cross-validation (leave-one-out approach). The optimal number of factors ranged between 3 to 6 and were selected considering the lowest standard error of cross-validation (SECV), and those factors explained 70.2 to $99.9 \%$ of the variance in the models.

For each regression model, the performance statistics both for the cross-validated calibration models and the external validation models were very similar (Table 3 ), which also confirms the robustness of the generated prediction models. Overall, FT-IR and Raman units performed superior to the NIR unit in terms of the correlation coefficient of validation $\left(\mathbf{R}_{\text {Pre }}\right)$ and standard error of prediction (SEP; Table 3). To provide a visual example, PLSR correlation plots were developed for the fat and protein contents using 3 different spectroscopic instruments (FT-IR, NIR, and Raman) and are given in Figure 6 . The performance statistics, including correlation coefficient of cross-validation $\left(\mathbf{R}_{\mathrm{CV}}\right), \mathrm{R}_{\mathrm{Pre}}, \mathrm{SECV}$, and SEP, showed similar or superior performances to previously reported studies using mainly the benchtop instruments (Table 4).

\section{CONCLUSIONS}

This study investigated the implementation of vibrational spectroscopy (NIR, FT-IR, and Raman) combined with pattern recognition analysis to monitor Turkish white cheese ripening and the prediction of the main quality parameters of cheese and the ripening indicator compounds. Combining the vibrational spectral data with SIMCA analysis, cheese samples at different ripening stages were clustered based on the compositional changes. The FT-IR and the Raman instruments offered higher discrimination when compared with the NIR spectroscopy. Furthermore, the same spectra were also used to generate the regression models to predict and observe the changes in the fat, protein, moisture, lactic acid, short-chain fatty acid, and total free amino acid content over $100 \mathrm{~d}$ of ripening period. The predictive models employed an optimal number of latent variables (3 to 6 ) to avoid overfitting. Furthermore, the FT-IR and the Raman units also provided superior 
A

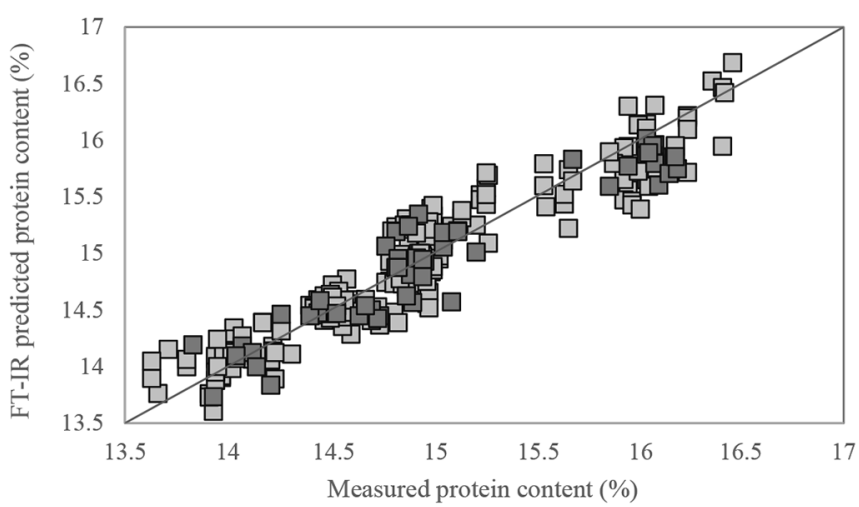

C

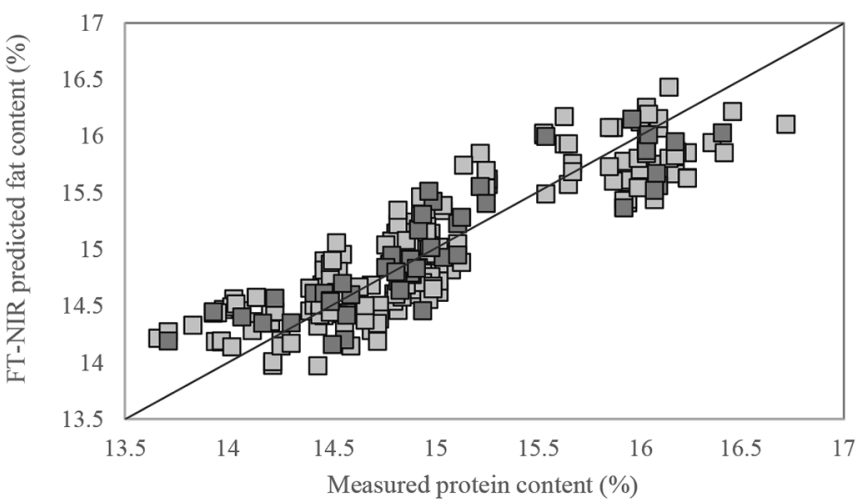

$\mathrm{E}$

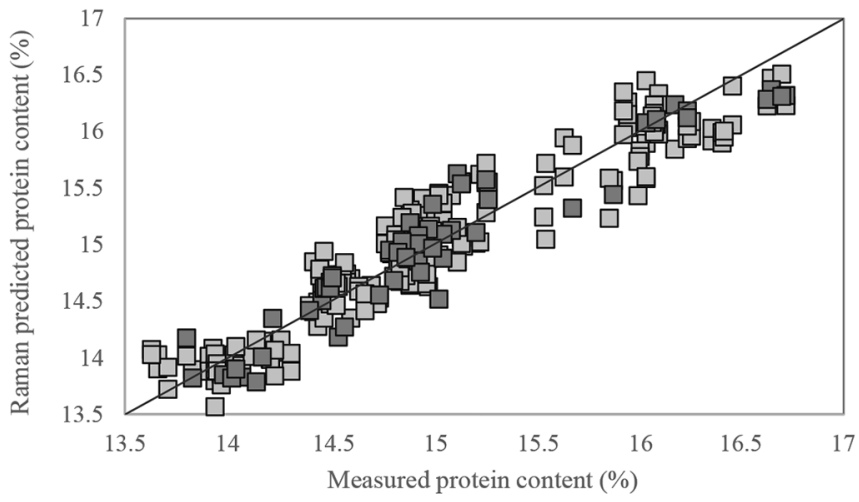

$\mathrm{B}$

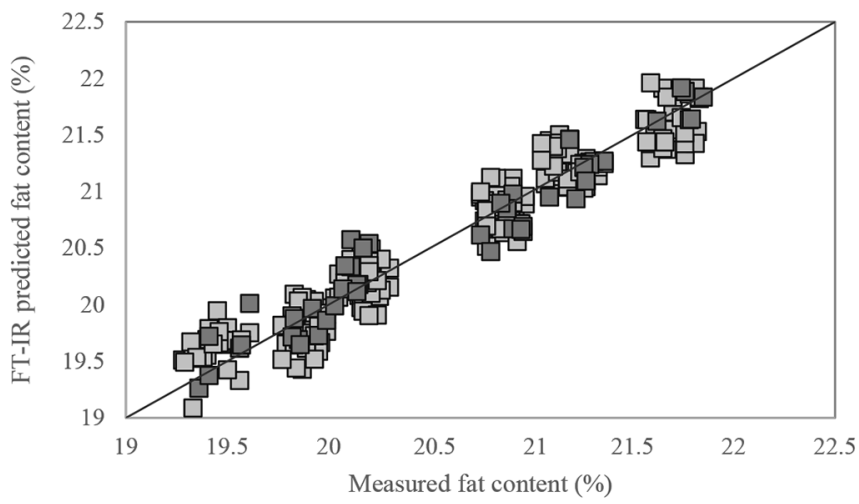

$\mathrm{D}$

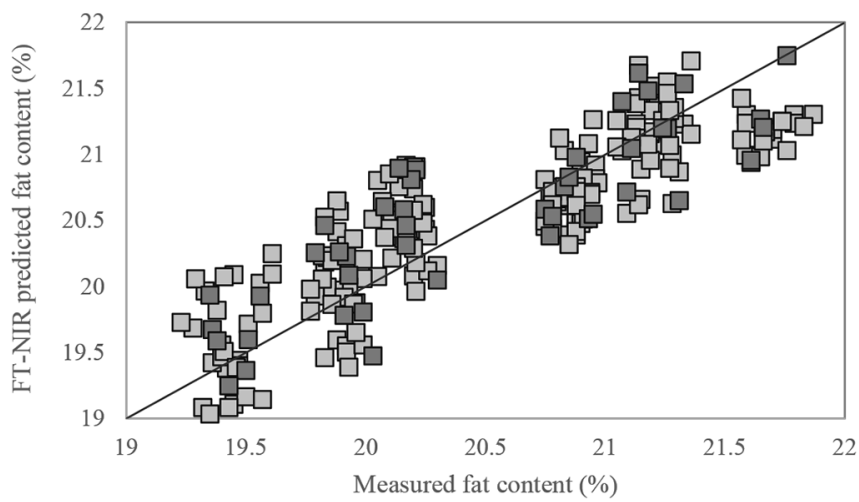

F

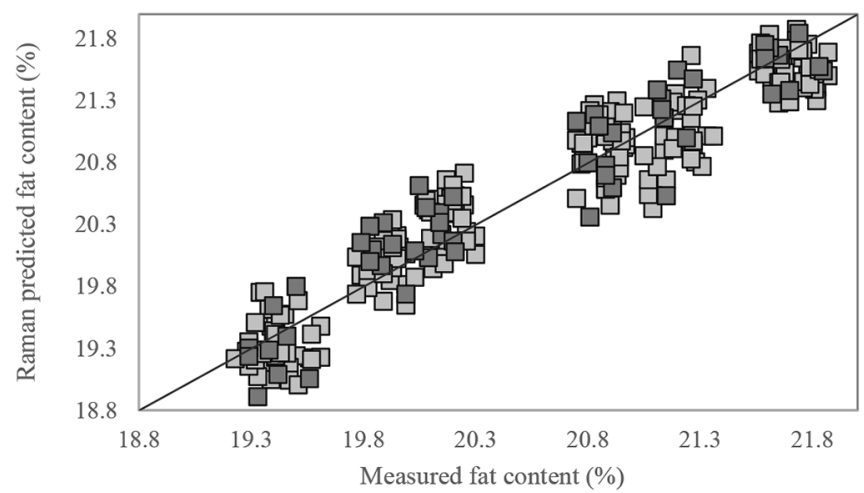

Figure 6. Partial least squares regression (PLSR) calibration and validation plots for the fat and protein levels in cheese samples using portable Fourier-transform infrared (FT-IR) (A, B), Fourier-transform near infrared (FT-NIR) (C, D), and Raman (E, F) instruments. White squares represent samples in calibration set; gray squares represent samples in external validation set.

performances than the NIR unit regarding the correlation coefficients and standard error of prediction in the PLSR models. Overall, all 3 techniques are useful methods to follow the ripening in a short-time and may help cheese producers monitor the biochemical kinetics and storage term.

\section{ACKNOWLEDGMENTS}

This research did not receive any specific grant from funding agencies in the public, commercial, or not-forprofit sectors. The author Hulya Yaman thanks The Scientific and Technological Research Council of Tur- 
Yaman et al.: RIPENING ATTRIBUTES OF TURKISH WHITE CHEESE

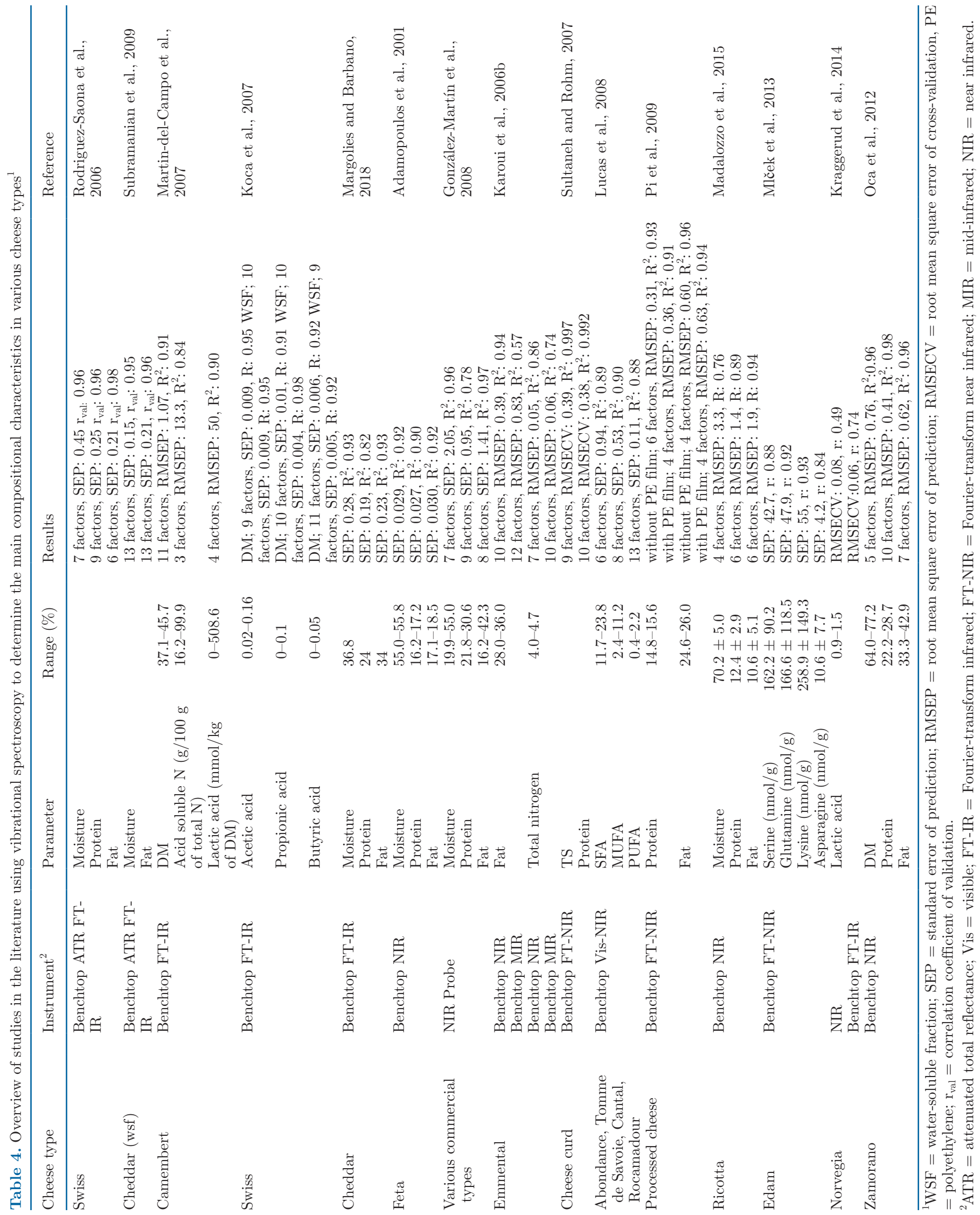


key (TUBITAK) for supporting her research at The Ohio State University. The authors have not stated any conflicts of interest.

\section{REFERENCES}

Adamopoulos, K. G., A. M. Goula, and H. J. Petropakis. 2001. Quality control during processing of feta cheese-NIR application. J. Food Compos. Anal. 14:431-440. https://doi.org/10.1006/jfca .2000 .0976 .

Alajtal, A. I., H. G. M. Edwards, M. A. Elbagerma, and I. J. Scowen. 2010. The effect of laser wavelength on the Raman Spectra of phenanthrene, chrysene, and tetracene: Implications for extraterrestrial detection of polyaromatic hydrocarbons.Spectrochim. Acta A Mol. Biomol. Spectrosc. 76:1-5. https://doi.org/10.1016/ j.saa.2010.01.009.

Argov, N., S. Wachsmann-Hogiu, S. L. Freeman, T. Huser, C. B. Lebrilla, and J. B. German. 2008. Size-dependent lipid content in human milk fat globules. J. Agric. Food Chem. 56:7446-7450. https: //doi.org/10.1021/jf801026a.

Atasoy, A. F., and H. Türkoğlu. 2008. Changes of composition and free fatty acid contents of Urfa cheeses (a white-brined Turkish cheese) during ripening: Effects of heat treatments and starter cultures. Food Chem. 110:598-604. https://doi.org/10.1016/j.foodchem 2008.02.046

Barth, A. 2007. Infrared spectroscopy of proteins. Biochim. Biophys. Acta. 1767:1073-1101. https://doi.org/10.1016/j.bbabio.2007.06 .004 .

Berrueta, L. A., R. M. Alonso-Salces, and K. Héberger. 2007. Supervised pattern recognition in food analysis. J. Chromatogr. A 1158:196-214. https://doi.org/10.1016/j.chroma.2007.05.024.

Boubellouta, T., and É. Dufour. 2012. Cheese-matrix characteristics during heating and cheese melting temperature prediction by synchronous fluorescence and mid-infrared spectroscopies. Food Bioprocess Technol. 5:273-284. https://doi.org/10.1007/s11947-010 $-0337-1$.

Boyaci, I. H., H. T. Temiz, H. E. Genis, E. A. Soykut, N. N. Yazgan, B. Guven, R. S. Uysal, A. G. Bozkurt, K. Ilaslan, O. Torun, and F. C. D. Seker. 2015. Dispersive and FT-Raman spectroscopic methods in food analysis. RCS Adv. 5:56606-56624. https://doi.org/10 $.1039 /$ C4RA12463D.

Boyanova, P., P. Panayotov, V. Ganchovska, and A. Bosakova-Ardenska. 2012. Microscopic method for qualification of the cut surface of white brined cheese. Agric. Sci. Technol. 4:306-310.

Büning-Pfaue, H. 2003. Analysis of water in food by near infrared spectroscopy. Food Chem. 82:107-115. https://doi.org/10.1016/ S0308-8146(02)00583-6.

Cevoli, C., A. Gori, M. Nocetti, L. Cuibus, M. F. Caboni, and A. Fabbri. 2013. FT-NIR and FT-MIR spectroscopy to discriminate competitors, non compliance and compliance grated Parmigiano Reggiano cheese. Food Res. Int. 52:214-220. https://doi.org/10 .1016/j.foodres.2013.03.016.

Checa-Moreno, R., E. Manzano, and L. F. Capitán-Vallvey. 2014. Characterisation and classification of binders used in art materials at the class and the subclass level. Anal. Methods 6:4009-4021. https://doi.org/10.1039/C4AY00444B.

Corvucci, F., L. Nobili, D. Melucci, and F.-V. Grillenzoni. 2015. The discrimination of honey origin using melissopalynology and Raman spectroscopy techniques coupled with multivariate analysis. Food Chem. 169:297-304. https://doi.org/10.1016/j.foodchem.2014.07 .122 .

Creamer, L. K. 1991. Electrophoresis of cheese. Bull. Int. Dairy Fed. 261:14-28.

Crocombe, R. A. 2018. Portable Spectroscopy. Appl. Spectrosc. 72:1701-1751. https://doi.org/10.1177/0003702818809719.

Czamara, K., K. Majzner, M. Z. Pacia, K. Kochan, A. Kaczor, and M. Baranska. 2015. Raman spectroscopy of lipids: A review. J. Raman Spectrosc. 46:4-20. https://doi.org/10.1002/jrs.4607.
De Gelder, J., K. De Gussem, P. Vandenabeele, and L. Moens. 2007. Reference database of Raman spectra of biological molecules. J. Raman Spectrosc. 38:1133-1147. https://doi.org/10.1002/jrs.1734.

Downey, G., E. Sheehan, C. Delahunty, D.O. O'Callaghan, T. Guinee, and V. Howard. 2005. Prediction of maturity and sensory attributes of Cheddar cheese using near-infrared spectroscopy. 15:701709. https://doi.org/10.1016/j.idairyj.2004.06.013.

El Soda, M., N. Farkye, J. C. Vuillemard, R. E. Simard, N. F. Olson, W. El Kholy, E. Dako, E. Medrano, M. Gaber, and L. Lim. 1995. Autolysis of lactic acid bacteria: Impact on flavour development in cheese. Pages 2205-2223 in Food Flavors: Generation, Analysis and Process Influence. G. Charalambous, ed. Elsevier Science.

Fagan, C. C., C. P. O'Donnell, D. J. O'Callaghan, G. Downey, E. M. Sheehan, C. M. Delahunty, C. Everard, T. P. Guinee, and V. Howard. 2007. Application of mid-infrared spectroscopy to the prediction of maturity and sensory texture attributes of Cheddar cheese. J. Food Sci. 72:E130-E137. https://doi.org/10.1111/j.1750 $-3841.2007 .00309 . x$.

Fox, P. F. 1989. Proteolysis during cheese manufacture and ripening. J. Dairy Sci. 72:1379-1400. https://doi.org/10.3168/jds.S0022 -0302(89)79246-8.

Furukawa, Y., H. Ohtsuka, M. Tasumi, I. Wataru, T. Kanbara, and T. Yamamoto. 1993. Raman studies of intact and sodium doped ${ }^{13} \mathrm{C}$ substituted poly-p-phenylene. J. Raman Spectrosc. 24:551-554. https://doi.org/10.1002/jrs.1250240814.

Genis, D. O., B. Sezer, S. Durna, and I. H. Boyaci. 2021. Determination of milk fat authenticity in ultra-filtered white cheese by using Raman spectroscopy with multivariate data analysis. Food Chem. 336:127699. https://doi.org/10.1016/j.foodchem.2020.127699.

González-Martín, I., C. González-Pérez, J. M. Hernández-Hierro, and J. M. González-Cabrera. 2008. Use of NIRS technology with a remote reflectance fibre-optic probe for predicting major components in cheese. Talanta 75:351-355. https://doi.org/10.1016/j .talanta.2007.11.028.

González-Martín, I., J. M. Hernández-Hierro, C. González-Pérez, I. Revilla, A. Vivar-Quintana, and I. Lobos Ortega. 2014. Potential of near infrared spectroscopy for the analysis of volatile components in cheeses. LWT Food Sci. Technol. 55:666-673. https://doi .org/10.1016/j.lwt.2013.10.008.

Grube, M., M. Bekers, D. Upite, and E. Kaminska. 2002. Infrared spectra of some fructans. Spectrosc. Int. J. 16:289-296. https:// doi.org/10.1155/2002/637587.

Hashimoto, K., V. R. Badarla, A. Kawai, and T. Ideguchi. 2019. Complementary vibrational spectroscopy. Nat. Commun. 10:4411. https://doi.org/10.1038/s41467-019-12442-9.

Hayaloglu, A. A., M. Guven, and P. F. Fox. 2002. Microbiological, biochemical and technological properties of Turkish White cheese "Beyaz Peynir." Int. Dairy J. 12:635-648. https://doi.org/10.1016/ S0958-6946(02)00055-9.

Innocente, N., S. Moret, C. Corradini, and L. S. Conte. 2000. A rapid method for the quantitative determination of short-chain free volatile fatty acids from cheese. J. Agric. Food Chem. 48:3321-3323. https://doi.org/10.1021/jf9908749.

International Dairy Federation. 2009. Milk and milk products — Determination of fat content - General guidance on the use of butyrometric methods. IDF.

ISO (International Organization for Standardization). 2002. ISO 14891:2002 Milk and milk products - Determination of nitrogen content - Routine method using combustion according to the Dumas principle. ISO. Accessed September 8, 2020. https://www .iso.org/standard/25871.html.

ISO (International Organization for Standardization). 2004. ISO 5534:2004 Cheese and processed cheese - Determination of the total solids content (Reference method). ISO. Accessed September 8, 2020. https://www.iso.org/standard/35249.html.

Izco, J. M., M. Tormo, and R. Jiménez-Flores. 2002. Rapid simultaneous determination of organic acids, free amino acids, and lactose in cheese by capillary electrophoresis. J. Dairy Sci. 85:2122-2129. https://doi.org/10.3168/jds.S0022-0302(02)74290-2.

Karoui, R., A. M. Mouazen, É. Dufour, L. Pillonel, E. Schaller, J. De Baerdemaeker, and J. O. Bosset. 2006a. Chemical characterisa- 
tion of European Emmental cheeses by near infrared spectroscopy using chemometric tools. Int. Dairy J. 16:1211-1217. https://doi .org/10.1016/j.idairyj.2005.10.002.

Karoui, R., A. M. Mouazen, É. Dufour, L. Pillonel, E. Schaller, D. Picque, J. De Baerdemaeker, and J. O. Bosset. 2006b. A comparison and joint use of NIR and MIR spectroscopic methods for the determination of some parameters in European Emmental cheese. Eur. Food Res. Technol. 223:44-50. https://doi.org/10.1007/ s00217-005-0110-2.

Kilcawley, K. N., M. G. Wilkinson, and P. F. Fox. 2001. A survey of lipolytic and glycolytic end-products in commercial Cheddar enzyme-modified cheese. J. Dairy Sci. 84:66-73. https://doi.org/ 10.3168/jds.S0022-0302(01)74453-0.

Koca, N., L. E. Rodriguez-Saona, W. J. Harper, and V. B. Alvarez. 2007. Application of Fourier transform infrared spectroscopy for monitoring short-chain free fatty acids in swiss cheese. J. Dairy Sci. 90:3596-3603. https://doi.org/10.3168/jds.2007-0063.

Koletzko, B., and R. Shamir. 2006. Standards for infant formula milk. BMJ 332:621-622. https://doi.org/10.1136/bmj.332.7542.621.

Kraggerud, H., T. Næs, and R. K. Abrahamsen. 2014. Prediction of sensory quality of cheese during ripening from chemical and spectroscopy measurements. Int. Dairy J. 34:6-18. https://doi.org/10 $.1016 /$ j.idairyj.2013.07.008.

Lambert, A., F. Bougrioua, O. Abbas, M. Courty, M. El Marssi, V. Faivre, and S. Bresson. 2018. Temperature dependent Raman and X-ray diffraction studies of anhydrous milk fat. Food Chem. 267:187-195. https://doi.org/10.1016/j.foodchem.2017.09.006.

Li-Chan, E. C. Y., A. A. Ismail, J. Sedman, and F. R. van de Voort. 2006. Vibrational spectroscopy of food and food products. Pages 3629-3662 in Handbook of Vibrational Spectroscopy. https://doi .org/10.1002/0470027320.s6501. Wiley.

Linden, A. 2006. Measuring diagnostic and predictive accuracy in disease management: An introduction to receiver operating characteristic (ROC) analysis. J. Eval. Clin. Pract. 12:132-139. https:// doi.org/10.1111/j.1365-2753.2005.00598.x.

Lucas, A., D. Andueza, A. Ferlay, and B. Martin. 2008. Prediction of fatty acid composition of fresh and freeze-dried cheeses by visiblenear-infrared reflectance spectroscopy. Int. Dairy J. 18:595-604. https://doi.org/10.1016/j.idairyj.2007.12.001.

Madalozzo, E. S., E. Sauer, and N. Nagata. 2015. Determination of fat, protein and moisture in ricotta cheese by near infrared spectroscopy and multivariate calibration. J. Food Sci. Technol. 52:1649 1655. https://doi.org/10.1007/s13197-013-1147-z.

Manuelian, C. L., S. Currò, M. Penasa, M. Cassandro, and M. De Marchi. 2017. Characterization of major and trace minerals, fatty acid composition, and cholesterol content of Protected Designation of Origin cheeses. J. Dairy Sci. 100:3384-3395. https://doi.org/10 $.3168 /$ jds.2016-12059

Margolies, B. J., and D. M. Barbano. 2018. Determination of fat, protein, moisture, and salt content of Cheddar cheese using midinfrared transmittance spectroscopy. J. Dairy Sci. 101:924-933. https://doi.org/10.3168/jds.2017-13431.

Marinoni, L., A. Stroppa, S. Barzaghi, K. Cremonesi, N. Pricca, A. Meucci, G. M. Pedrolini, A. Galli, and G. Cabassi. 2019. On site monitoring of Grana Padano cheese production using portable spectrometers. Pages 85-90 in Proc. 18th Int. Conf. Near Infrared Spectrosc. S. B. Engelsen, K. M. Sørensen, and F. van den Berg, ed. IM Publications Open. https://doi.org/10.1255/nir2017.085.

Martín-del-Campo, S. T., D. Picque, R. Cosio-Ramirez, and G. Corrieu. 2007. Evaluation of chemical parameters in soft mold-ripened cheese during ripening by mid-infrared spectroscopy. J. Dairy Sci. 90:3018-3027. https://doi.org/10.3168/jds.2006-656.

McSweeney, P. L. H., and M. J. Sousa. 2000. Biochemical pathways for the production of flavour compounds in cheeses during ripening: A review. Lait 80:293-324. https://doi.org/10.1051/lait:2000127.

Mlček, J., K. Šustová, O. Rop, T. Juríková, P. Humpolíček, and Š. Balla. 2013. Rapid assessment of selected free amino acids during Edam cheese ripening by near infrared spectroscopy. Acta Vet. Brno 82:191-196. https://doi.org/10.2754/avb201382020191.

Ngarize, S., H. Herman, A. Adams, and N. Howell. 2004. Comparison of changes in the secondary structure of unheated, heated, and high-pressure-treated beta-lactoglobulin and ovalbumin proteins using fourier transform Raman spectroscopy and self-deconvolution. J. Agric. Food Chem. 52:6470-6477. https://doi.org/10 $.1021 /$ jf030649y.

Nicolaou, N., Y. Xu, and R. Goodacre. 2010. Fourier transform infrared spectroscopy and multivariate analysis for the detection and quantification of different milk species. J. Dairy Sci. 93:5651-5660. https://doi.org/10.3168/jds.2010-3619.

Oca, M. L., M. C. Ortiz, L. A. Sarabia, A. E. Gredilla, and D. Delgado. 2012. Prediction of Zamorano cheese quality by near-infrared spectroscopy assessing false non-compliance and false compliance at minimum permitted limits stated by designation of origin regulations. Talanta 99:558-565. https://doi.org/10.1016/j.talanta .2012.06.035.

Oleszko, A., S. Olsztyńska-Janus, T. Walski, K. Grzeszczuk-Kuć, J. Bujok, K. Gałecka, A. Czerski, W. Witkiewicz, and M. Komorowska. 2015. Application of FTIR-ATR spectroscopy to determine the extent of lipid peroxidation in plasma during haemodialysis. Biomed Res. Int. 2015:245607. https://doi.org/10.1155/2015/ 245607.

Ottavian, M., P. Facco, M. Barolo, P. Berzaghi, S. Segato, E. Novelli, and S. Balzan. 2012. Near-infrared spectroscopy to assist authentication and labeling of Asiago d'allevo cheese. J. Food Eng. 113:289-298. https://doi.org/10.1016/j.jfoodeng.2012.05.037.

Otte, J., Y. Ardo, B. Weimer, and J. Sorensen. 1999. Capillary electrophoresis used to measure proteolysis in cheese. Int. Dairy Fed. Bull. 337:10-16.

Özer, B., H. A. Kirmaci, A. A. Hayaloglu, M. Akçelik, and N. Akkoç. 2011. The effects of incorporating wild-type strains of Lactococcus lactis into Turkish white-brined cheese (Beyaz peynir) on the fatty acid and volatile content. Int. J. Dairy Technol. 64:494-501. https: //doi.org/10.1111/j.1471-0307.2011.00683.x.

Partidario, A. M., M. Barbosa, and L. V. Boas. 1998. Free fatty acids, triglycerides and volatile compounds in Serra da Estrela cheesechanges throughout ripening. Int. Dairy J. 8:873-881.

Pézolet, M., M. Pigeon-Gosselin, J. Nadeau, and J. P. Caillé. 1980. Laser Raman scattering. A molecular probe of the contractile state of intact single muscle fibers. Biophys. J. 31:1-8. https://doi.org/ 10.1016/S0006-3495(80)85036-3.

Pi, F., H. Shinzawa, Y. Ozaki, and D. Han. 2009. Non-destructive determination of components in processed cheese slice wrapped with a polyethylene film using near-infrared spectroscopy and chemometrics. Int. Dairy J. 19:624-629. https://doi.org/10.1016/ j.idairyj.2009.05.002.

Podstawka, E., M. Swiatłowska, E. Borowiec, and L. M. Proniewicz. 2007. Food additives characterization by infrared, Raman, and surface-enhanced Raman spectroscopies. J. Raman Spectrosc. 38:356-363. https://doi.org/10.1002/jrs.1653.

Posati, L. P., and M. L. Orr. 1976. Composition of Foods: Dairy and Egg Products: Raw, Processed, Prepared. Agricultural Research Service, USDA.

Prabhakar, V., N. Kocaoglu-Vurma, J. Harper, and L. Rodriguez-Saona. 2011. Classification of Swiss cheese starter and adjunct cultures using Fourier transform infrared microspectroscopy. J. Dairy Sci. 94:4374-4382. https://doi.org/10.3168/jds.2011-4457.

Ren, H., J. D. Biggs, and S. Mukamel. 2013. Two-dimensional stimulated ultraviolet resonance Raman spectra of tyrosine and tryptophan: A simulation study. J. Raman Spectrosc. 44:544-559. https: //doi.org/10.1002/jrs.4210.

Rodriguez-Saona, L., D. P. Aykas, K. R. Borba, and A. Urtubia. 2020 Miniaturization of optical sensors and their potential for highthroughput screening of foods. Curr. Opin. Food Sci. 31:136-150. https://doi.org/10.1016/j.cofs.2020.04.008.

Rodriguez-Saona, L. E., N. Koca, W. J. Harper, and V. B. Alvarez. 2006. Rapid determination of swiss cheese composition by Fourier transform infrared/attenuated total reflectance spectroscopy. J. Dairy Sci. 89:1407-1412. https://doi.org/10.3168/jds.S0022 -0302(06)72209-3.

Rygula, A., K. Majzner, K. M. Marzec, A. Kaczor, M. Pilarczyk, and M. Baranska. 2013. Raman spectroscopy of proteins: A review. J. Raman Spectrosc. 44:1061-1076. https://doi.org/10.1002/jrs.4335. 
Schweitzer-Stenner, R., F. Eker, Q. Huang, K. Griebenow, P. A. Mroz, and P. M. Kozlowski. 2002. Structure analysis of dipeptides in water by exploring and utilizing the structural sensitivity of amide III by polarized visible Raman, FTIR-spectroscopy and DFT based normal coordinate analysis. J. Phys. Chem. B 106:4294-4304. https://doi.org/10.1021/jp0137118.

Sert, D., N. Akin, and A. Aktumsek. 2014. Lipolysis in Tulum cheese produced from raw and pasteurized goats' milk during ripening. Small Rumin. Res. 121:351-360. https://doi.org/10.1016/j .smallrumres.2014.06.006.

Shenk, J. S., J. J. Workman, and M. O. Westerhaus. 2008. Application of NIR Spectroscopy to Agricultural Products. 3rd ed. D. A. Burns and E. W. Ciurczak, ed. CRC Press.

Smith, G. P. S., S. E. Holroyd, D. C. W. Reid, and K. C. Gordon. 2017. Raman imaging processed cheese and its components. J. Raman Spectrosc. 48:374-383. https://doi.org/10.1002/jrs.5054.

Sowoidnich, K., and H. Kronfeldt. 2016. Shifted excitation Raman difference spectroscopy for authentication of cheese and cheese analogues. Proceedings Volume 9887 Biophotonics: Photonic Solutions for Better Health Care V.

Subramanian, A., V. B. Alvarez, W. J. Harper, and L. E. RodriguezSaona. 2011. Monitoring amino acids, organic acids, and ripening changes in Cheddar cheese using Fourier-transform infrared spectroscopy. Int. Dairy J. 21:434-440. https://doi.org/10.1016/j .idairyj.2010.12.012.
Subramanian, A., W. J. Harper, and L. E. Rodriguez-Saona. 2009 Rapid prediction of composition and flavor quality of cheddar cheese using ATR-FTIR spectroscopy. J. Food Sci. 74:C292-C297. https://doi.org/10.1111/j.1750-3841.2009.01111.x.

Sultaneh, A., and H. Rohm. 2007. Using near infrared spectroscopy for the determination of total solids and protein content in cheese curd. Int. J. Dairy Technol. 60:241-244. https://doi.org/10.1111/j .1471-0307.2007.00347.x.

Trebolazabala, J., M. Maguregui, H. Morillas, A. De Diego, and J. M. Madariaga. 2013. Use of portable devices and confocal Raman spectrometers at different wavelength to obtain the spectral information of the main organic components in tomato (Solanum lycopersicum) fruits. Spectrochim. Acta Part A Mol. Biomol. Spectrosc. 105:391-399. https://doi.org/10.1016/j.saa.2012.12.047.

Vogt, N. B., and H. Knutsen. 1985. SIMCA pattern recognition classification of five infauna taxonomic groups using non-polar compounds analysed by high resolution gas chromatography. Mar. Ecol. Prog. Ser. 26:145-156. https://doi.org/10.3354/meps026145.

Walstra, P., J. T. M. Wouters, and T. J. Geurts. 2006. Dairy Science and Technology. 2nd ed. Taylor \& Francis Group.

Zając, A., J. Hanuza, and L. Dyminska. 2014. Raman spectroscopy in determination of horse meat content in the mixture with other meats. Food Chem. 156:333-338. https://doi.org/10.1016/j foodchem.2014.02.002. 